\title{
Clonal Evolution of Acute Myeloid Leukemia with CEBPA Double Mutations after Long-Term Remission: Case Report and a Literature Review
}

\author{
Uzun Süreli Remisyon sonrası CEBPA Çift Mutasyonu ile Akut Myeloid Löseminin Klonal \\ Evolüsyonu: Olgu Sunumu ve Bir Literatür Derlemesi
}

(D) Ying Li1, (D) Long Su²

${ }^{1}$ Changchun Central Hospital, Clinic of Hematology, Changchun, China

2 Jilin University the First Hospital, Clinic of Hematology, Changchun, China

To the Editor,

Mutations in the CEBPA gene occur in 7\%-15\% of all acute myeloid leukemia (AML) patients $[1,2]$. However, we found that the frequency of such mutation may be high in Chinese AML patients $[3,4]$. Although AML with CEBPA double mutations (CEBPAdm) indicates a favorable outcome, recent data show that more than $50 \%$ of patients finally relapsed when consolidated with chemotherapy alone [5]. Clonal evolution (CE) is an important factor for relapse [6]. However, studies discussing CE in AML patients with CEBPAdm are limited $[7,8]$. Here, we report CE in two patients with CEBPAdm determined by sensitive nextgeneration sequencing (NGS).

Two female AML patients were diagnosed in our hospital in January 2012 and September 2013. Standard ' $3+7$ ' induction chemotherapy was administered. Both of them achieved CR after induction therapy. Patient 1 received consolidation therapy with one course of DA (daunorubicin + cytarabine), four courses of high-dose cytarabine (HD-Ara-C), and one course of DA. Patient 2 received consolidation therapy with three courses of HD-Ara-C and two courses of immunotherapy. After long-term remissions (63 and 40 months), they both relapsed. Cytogenetic and fusion gene analyses indicated no difference from diagnosis. NGS analysis indicated altered mutations sites of the CEBPA gene in Patient 2 (Figure 1). New co-occurring mutations emerged at relapse: SETD2 mutation in Patient 1 and WT1 mutation in Patient 2 (Table 1). After relapse, Patient 1 achieved CR with a DA regimen and Patient 2 refused treatment.

The first report for CE in patients with CEBPAdm included two patients [7]. In the first patient, the amino-terminal frameshift mutation was duplicated and found on both alleles at relapse. In the second patient, the amino-terminal frame-shift

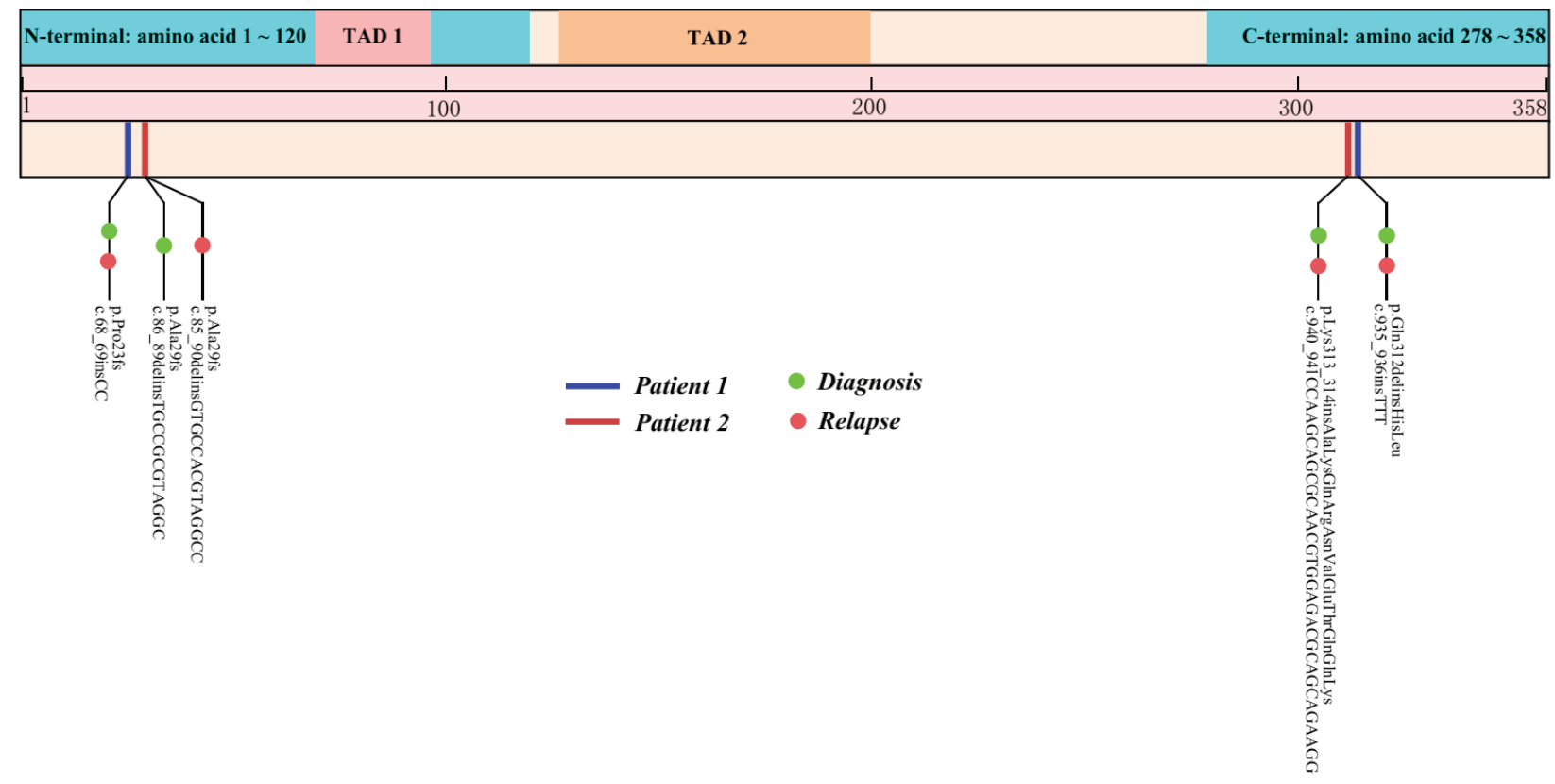

Figure 1. CEBPA gene mutations of these two patients at diagnosis and relapse. 


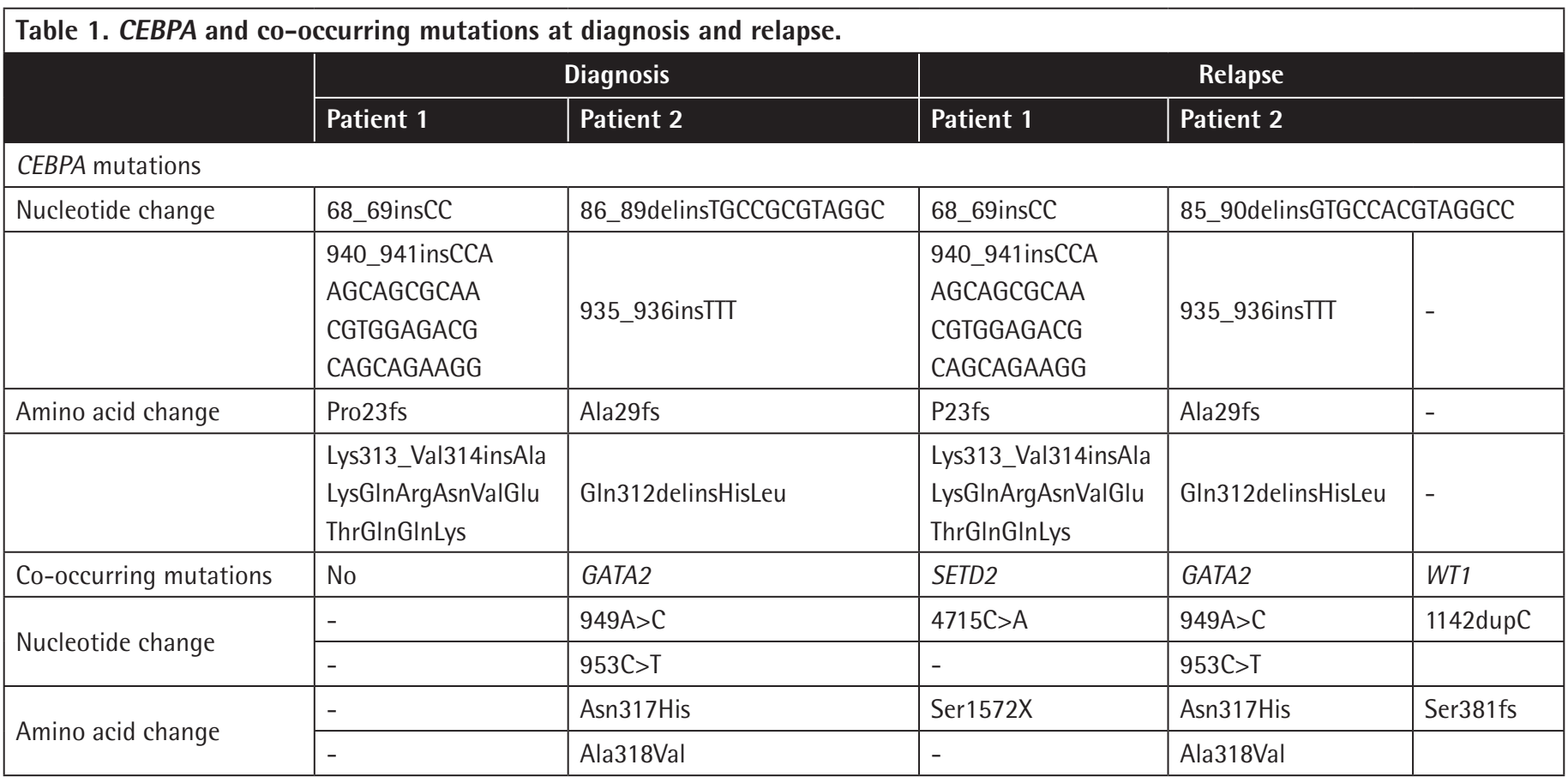

mutation and a mutation in the fork region were found either alone or combined on the same allele, suggesting a subclone formation [7]. Another study reported CE in 22 patients; two of them lost mutations and none acquired new mutation at relapse [8]. Twenty patients harboring CEBPA mutations relapsed with identical mutation patterns; three of them had a second relapse that also exhibited the same patterns as their initial diagnosis and first relapse [8]. Two patients had concomitant FLT3-ITD mutations at diagnosis and one was lost at relapse. Two patients acquired FLT3-TKD mutations at relapse. N-RAS mutations were detected in three patients at diagnosis and two of them retained the identical mutation at relapse [8]. In this case report, we found mutation site alteration in the CEBPA gene and two newly emerged co-occurring mutations.

CE of patients with CEBPAdm can be summarized as follows: 1) allele alteration of $C E B P A$ gene: acquire or lose mutation site in allele; 2) mutation site alteration in CEBPA gene: acquire or lose mutation site in CEBPA gene other than allele; 3) co-occurring mutation alteration: acquire or lose co-occurring mutation. One issue that needs to be resolved is the relationship between time and CE after CR. In this case report, these two patients relapsed after long-term remissions, and new co-occurring mutations emerged in both of them. Hence, whether late relapse is associated with new co-occurring mutations is unknown.

\section{Acknowledgments}

We thank the Department of Hematology of the First Hospital, Bethune Medical College of Jilin University, for assistance in this work. Informed consent was obtained from the patients or their relatives for this case report.
Keywords: Acute myeloid leukemia, CEBPA mutations, Nextgeneration sequencing, Clonal evolution, Relapse

Anahtar Sözcükler: Akut myeloid lösemi, CEBPA mutasyonu, Yeni nesil dizileme, Klonal evolüsyon, Relaps

Informed Consent: Received.

Conflict of Interest: The authors of this paper have no conflicts of interest including specific financial interests, relationships, and/or affiliations relevant to the subject matter or materials included.

\section{References}

1. Dufour A, Schneider $F$, Metzeler KH, Hoster $E$, Schneider S, Zellmeier $E$, Benthaus T, Sauerland MC, Berdel WE, Büchner T, Wörmann B, Braess J, Hiddemann W, Bohlander SK, Spiekermann K. Acute myeloid leukemia with biallelic CEBPA gene mutations and normal karyotype represents a distinct genetic entity associated with a favorable clinical outcome. J Clin Oncol 2010;28:570-577.

2. Fasan $A$, Haferlach $C$, Alpermann $T$, Jeromin $S$, Grossmann V, Eder $C$, Weissmann S, Dicker F, Kohlmann A, Schindela S, Kern W, Haferlach $T$, Schnittger $\mathrm{S}$. The role of different genetic subtypes of CEBPA mutated AML. Leukemia 2014;28:794-803.

3. Su L, Gao S, Liu X, Tan Y, Wang L, Li W. CEBPA mutations in patients with de novo acute myeloid leukemia: data analysis in a Chinese population. Onco Targets Ther 2016;9:3399-3403.

4. Su L, Tan Y, Lin H, Liu X, Yu L, Yang Y, Liu S, Bai O, Yang Y, Jin F, Sun J, Liu C, Liu Q, Gao S, Li W. Mutational spectrum of acute myeloid leukemia patients with double CEBPA mutations based on next-generation sequencing and its prognostic significance. Oncotarget 2018;9:2497024979.

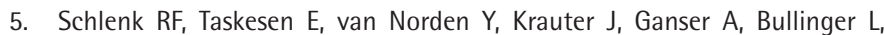
Gaidzik VI, Paschka P, Corbacioglu A, Göhring G, Kündgen A, Held G, Götze K, Vellenga E, Kuball J, Schanz U, Passweg J, Pabst T, Maertens J, Ossenkoppele GJ, Delwel R, Döhner H, Cornelissen JJ, Döhner K, Löwenberg B. The value 
of allogeneic and autologous hematopoietic stem cell transplantation in prognostically favorable acute myeloid leukemia with double mutant CEBPA. Blood 2013;122:1576-1582.

6. Graubert TA, Brunner AM, Fathi AT. New molecular abnormalities and clonal architecture in AML: from reciprocal translocations to whole-genome sequencing. Am Soc Clin Oncol Educ Book 2014:334-340.
7. Tiesmeier J, Czwalinna A, Müller-Tidow C, Krauter J, Serve H, Heil G, Ganser A, Verbeek W. Evidence for allelic evolution of C/EBPalpha mutations in acute myeloid leukaemia. Br J Haematol 2003;123:413-419.

8. Shih LY, Liang DC, Huang CF, Wu JH, Lin TL, Wang PN, Dunn P, Kuo MC, Tang TC. AML patients with CEBPA mutations mostly retain identical mutant patterns but frequently change in allelic distribution at relapse: a comparative analysis on paired diagnosis and relapse samples. Leukemia 2006;20:604-609.

๑Copyright 2019 by Turkish Society of Hematology

Turkish Journal of Hematology, Published by Galenos Publishing House

\title{
Progressive Hepatic Cirrhosis Early After Allogeneic Hematopoietic Stem Cell Transplantation in a Patient with Chronic Hepatitis C Infection
}

\author{
Kronik Hepatit C Enfeksiyonu Olan Hastada Allojenik Kök Hücre Nakli Sonrası Erken \\ Dönemde Progresif Karaciğer Sirozu
}

\author{
(1) Satoshi Kaito1, (1) Noriko Doki ${ }^{1}$, (1) Tsunekazu Hishima22, (1) Yasunobu Takaki³, (1) Kazuteru Ohashi1 \\ ${ }^{1}$ Tokyo Metropolitan Cancer and Infectious Diseases Center, Komagome Hospital, Hematology Division, Tokyo, Japan \\ 2Tokyo Metropolitan Cancer and Infectious Diseases Center, Komagome Hospital, Pathology Division, Tokyo, Japan \\ ${ }^{3}$ Tokyo Metropolitan Cancer and Infectious Diseases Center, Komagome Hospital, Radiology Division, Tokyo, Japan
}

To the Editor,

Hepatitis C virus (HCV)-infected allogeneic hematopoietic stem cell transplantation (allo-HSCT) recipients have a higher incidence of liver cirrhosis over long-term follow-up compared to recipients without HCV infection [1,2]. However, liver dysfunction related to HCV is usually mild in the first 3 months after allo-HSCT [3]. We present the progressive hepatic cirrhosis soon after allo-HSCT in an HCV-infected recipient. The clinical and histopathological features were very similar to fibrosing cholestatic hepatitis $(\mathrm{FCH})$ caused by $\mathrm{HCV}$ reactivation.

A 50-year-old woman with myelodysplastic syndrome with excess blasts- 1 was admitted to undergo allo-HSCT. The patient had a history of hepatitis $\mathrm{C}$ positivity (genotype 2a) for more than 20 years. Liver enzyme levels at admission were slightly elevated (aspartate aminotransferase $57 \mathrm{U} / \mathrm{L}$, alanine aminotransferase $61 \mathrm{U} / \mathrm{L}$, alkaline phosphatase $434 \mathrm{U} / \mathrm{L}$, cholinesterase $115 \mathrm{U} / \mathrm{L}$, total bilirubin (T-Bil) $1.2 \mathrm{mg} / \mathrm{dL}$, and hepatitis $C$ viral load $2.5 \times 10^{4} \mathrm{IU} / \mathrm{mL}$ ). The serological tests for hepatitis B virus (HBV) and polymerase chain reaction for HBV-DNA were negative. Computed tomography (CT) demonstrated hepatosplenomegaly. Abdominal ultrasonography (US) showed coarse hepatic echostructure over the entire liver with a dull edge, smooth surface, and straight hepatic vein without ascites or any signs of portal hypertension. Liver biopsy was not performed because of thrombocytopenia.

Just before transplantation, no risk factors except for the mild hepatic dysfunction and age were found, the hematopoietic cell transplantation-comorbidity index ( $\mathrm{HCT}-\mathrm{Cl}$ ) was 1 , and the age-adjusted HCT-Cl score was $2[4,5]$. Meanwhile, bone marrow examination revealed active disease with 6.7\% myeloblasts. Considering the situation, the patient underwent peripheral blood stem cell transplantation from her human leukocyte antigen-identical sibling after myeloablative conditioning with cyclophosphamide $(120 \mathrm{mg} / \mathrm{kg})$ and total body irradiation (12 Gy). Considering drug-induced liver dysfunction, we avoided the use of busulfan. Cyclosporine and short-term methotrexate were used for graft-versus-host disease (GVHD) prophylaxis. After neutrophil engraftment, T-Bil was elevated up to $8.3 \mathrm{mg} / \mathrm{dL}$ and hepatitis $\mathrm{C}$ viral load was noted to have increased to $4.0 \times 10^{6} \mathrm{IU} / \mathrm{mL}$ on day 36 after allo-HSCT. Methylprednisolone was started at $1 \mathrm{mg} / \mathrm{kg} /$ day on day 36 for acute GVHD, with gradual improvement in liver test results. We performed deliberate observation of the patient with weekly US and monthly CT 